\title{
The USGS Earthquake Hazards Program in NEHRP- Investing in a Safer Future
}

In 1977, Congress authorized the
creation of the National Earth-
quake Hazards Reduction Program
(NEHRP) to improve the Nation's
understanding of earthquake haz-
ards and to mitigate their effects.
Earthquakes are the most costly
natural hazard faced by the United
States. Twenty-five years of work by
the U.S. Geological Survey (USGS),
in close cooperation with the three
other NEHRP agencies, has yielded
major advances in earthquake pre-
paredness and monitoring, as weII
as a vastly improved understanding
of earthquake hazards, processes,
and effects. The USGS is poised to
build on these accomplishments,
helping through NEHRP to protect
lives and property in the future
earthquakes that are certain to
strike the United States.

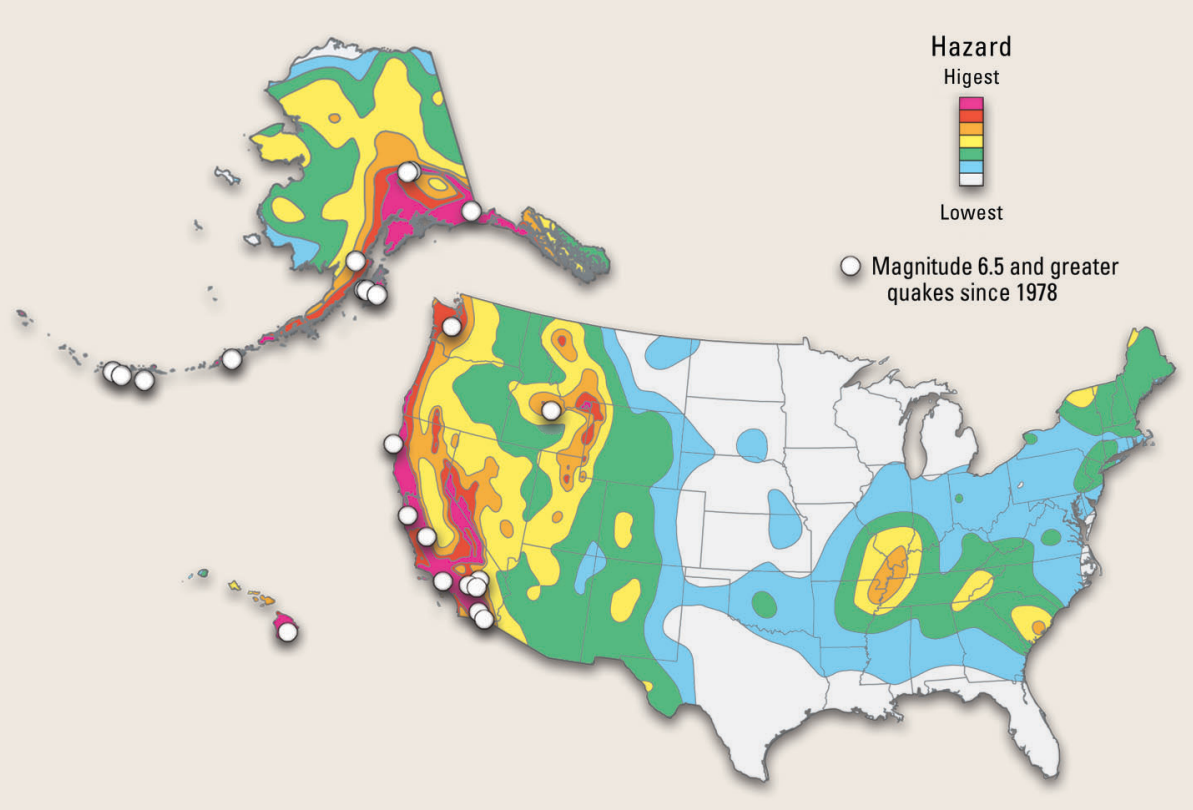

As shown by this U.S. Geological Survey (USGS) national seismic-hazard map, earthquake hazards exist throughout the United States. USGS national and regional seismic-hazard maps forecast the amount of shaking expected over specified time periods. Many parts of the Central and Eastern United States have moderate to high long-term hazard, even though they have not experienced recent large quakes. Successive updates of USGS seismic-hazard maps are used to revise building codes and are also widely used by structural engineers and government agencies. The next generation of such maps will provide time-dependent probabilities that take into account the effects of prior quake occurrence on future earthquake likelihood.
The U.S. Geological Survey (USGS) Earthquake Hazards Program monitors the Nation's earthquakes, studies why they occur and how they shake the ground, provides quantitative earthquake-hazard assessments, helps promote loss-reduction measures using these results, and provides crucial scientific information to assist emergency responders when earthquakes occur. The USGS Earthquake Hazards Program operates under the National Earthquake Hazards Reduction Program (NEHRP), created by Congress in 1977. To meet the challenges and potential of NEHRP, activities supported by the USGS Earthquake Hazards Program are managed under four broad interrelated objectives:

- Improve quantification of seismic hazards - The USGS produces quantitative hazard-assessment products that enable the public and private sectors to assess earthquake hazards and implement effective mitigation strategies.

- Complete the modernization and expansion of real-time earthquake notification and monitoring systems-The USGS is tasked with collecting, interpreting, and disseminating information on the earthquakes that occur throughout the United States and on significant quakes worldwide in support of disaster response, earthquake preparedness, national security, scientific research, and public hazard awareness.

- Achieve better scientific understanding of earthquake processes and effects-The USGS pursues research on earthquake occurrence and effects for the purpose of developing and improving hazard-assessment methods and loss-reduction strategies.

- Provide national and local leadership to engage communities in earthquake safety practices-The USGS works with user communities to ensure that its products are readily available, easily understood, and appropriately used for earthquake mitigation and response.

The work of the USGS Earthquake Hazards Program focuses both on the Nation as a whole and also on particular regional needs and problems in areas where quake risk is the greatest. The program's work is carried out by USGS scientific and technical personnel and also through a system of competitive external grants and contracts that is allotted one-quarter of program funds. In the past 25 years, this grants program has funded approximately 2,500 grants and cooperative agreements with state geological surveys, university researchers and research consortia, state and local government agencies, and nonprofit and other organizations in the private sector. USGS also works closely with the other NEHRP agencies (FEMA, NSF, and the National Institute of Standards and Technology) and with non-NEHRP agencies, such as NASA, NOAA, and USAID. 
UNDERSTANDING THE PHYSICS OF EARTHQUAKES

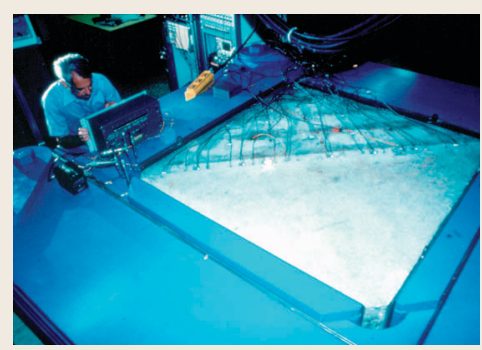

SAN ANDREAS FAULT MODEL



U.S. Geological Survey (USGS) rock-mechanics laboratories have been the birthplace of a stream of breakthroughs on the nature of rock friction and its control of earthquakes - their size, rate, interactions, and the ground shaking they produce. These studies, in combination with extensive field tests, have led to new theories about the physics of faulting and the role of fluids in quake generation. USGS is now poised to directly test these theories not just on laboratory scale models (left) but also at a depth of 2.5 miles in the San Andreas Fault (right) at Parkfield, California. There, the San Andreas Fault Observatory at Depth (SAFOD) is being built in partnership with the National Science Foundation (NSF) as part of the EarthScope program. The 1.3-mile-deep SAFOD pilot hole was successfully completed in 2002.

\section{Accomplishments and Impacts of the USGS Earthquake Hazards Program}

Over the past 25 years, NEHRP has made the Nation safer from the ravages of earthquakes. One of the flagship products from NEHRP contributing to this achievement are the national seismic-hazard maps that the USGS has produced since 1976. These maps are derived by estimating the likelihood of future earthquakes along active faults throughout different regions and evaluating the ground shaking that these quakes would cause. These seismichazard maps are the scientific basis of seismic provisions in building codes enacted throughout the United States to prevent loss of life and limit damage during large earthquakes. The 1996 national seismic-hazard maps are directly included in design maps in the NEHRP Recommended Provisions, published by the Building Seismic Safety Council and the Federal Emergency Management Agency (FEMA). Seismic provisions in both the 2000 International Building Code (the merging of the three major national model codes) and the International Residential Code are also derived from these maps. These codes have now been adopted by jurisdictions in 37 states. Thus, the USGSproduced national seismic-hazard maps are now being used to make billions of dollars of new construction each year safer from earthquakes.

The national seismic-hazard maps are also used in FEMA's retrofit guidelines, ensuring that older buildings are strengthened so that they withstand future earthquakes. In addition, these maps and associated products are used in the design of highway bridges, landfills under EPA regulation, and dams, as well as in the setting of earthquake-insurance premiums and the cost of reinsurance. The California Earthquake Authority uses seismic-hazard maps produced jointly by the USGS and the California Geological Survey to set earthquake premiums for the State's quake-insurance program. Pension funds apply these maps to evaluate the risks to their portfolios of properties. Presidential executive orders specify that new and leased Federal buildings must adhere to the NEHRP Recommended Provisions. The State of Oregon recently raised seismic requirements in construction along the southern part of its coast, largely on the basis of information presented in the USGS seismic-hazard maps.

The advances in earthquake-hazard assessments during the first 25 years of NEHRP have their roots in pioneering USGS field, laboratory, and theoretical research focused on understanding the basic physical processes associated with earthquakes. Key breakthroughs include:

- Improved quantification of regional seismic-energy attenuation with distance from an earthquake.

- Use of Global Positioning System (GPS) stations to determine the rate at which faults are being "loaded" (stressed) by the movements of the tectonic plates that make up the Earth's outer shell.

- Discovery and documentation of large prehistoric earthquakes through a new field of study known as paleoseismology (identifying evidence of past quakes in trenches dug across faults, in riverbanks, and from drowned coastlines).

- Use of new remote-sensing technology, such as LIDAR (light detection and ranging), to identify active faults in heavily forested regions like the Pacific Northwest.

- Quantification of the effects of soils and near-surface conditions in amplifying strong ground motion.

- Advances in earthquake forecasting through improved understanding of the physics of the fracture and friction of rocks in fault zones.

\section{EARTHOUAKE DETECTIVE WORK REVEALS PREVIOUSLY UNKNOWN HAZARDS}

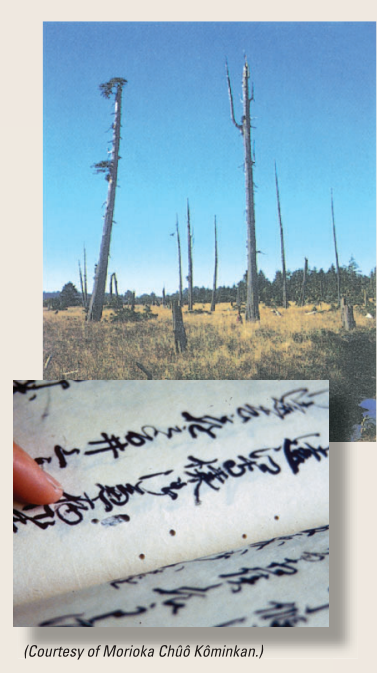

In the 1980's, U.S. Geological Survey (USGS) scientists discovered the first evidence that very large earthquakes have repeatedly struck the Pacific Northwest in the past. Geologic and tree-ring studies showed that a strong earthquake of unknown magnitude struck the region in about 1700, a century before the Lewis and Clark expedition. Trees (left) died when coastal areas were lowered during the quake, submerging their roots in saltwater. In the 1990's, clues to this quake's magnitude were found by USGS and Japanese researchers in 300-year-old administrative records from Japan (lower left). Those records describe the effects of a destructive tsunami (seismic sea wave) that occurred without the usual warning of a nearby earthquake. The scientists pieced these and other clues together and determined that only an extraordinarily powerful earthquake from across the Pacific Ocean could have generated this tsunami. They concluded that a quake of magnitude 9 struck the Pacific Northwest on the evening of January 26, 1700, releasing 30 times as much energy as the largest quake ever recorded in California.

When this potential for magnitude 9 earthquakes offshore Washington and Oregon was recognized, USGS and the Federal Emergency. Management Agency (FEMA) helped to form the Cascadia Region Earthquake Workgroup (CREW), which has involved Federal and local government officials with business and industrial interests to jointly and effectively address earthquake hazards and promote mitigation in the Pacific Northwest. USGS earthquake-hazard maps (right) that are used to set building codes were also revised to reflect the recently identified hazard in the Pacific Northwest.
USGS SHAKING-HAZARD MAPS
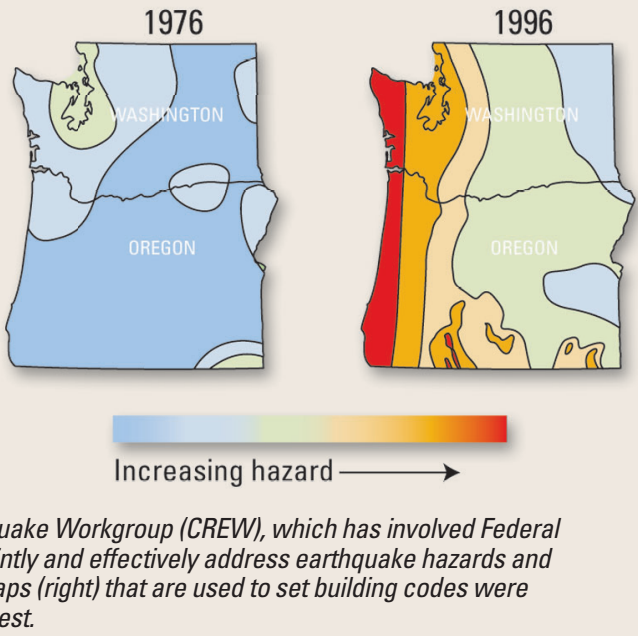


\section{"SHAKEMAP"—A NEW TECHNOLOGY TO AID EMERGENCY RESPONSE}

PNSN Rapid Instrumental Intensity Map Epicenter: 17.0 km NE of Olympia, WA

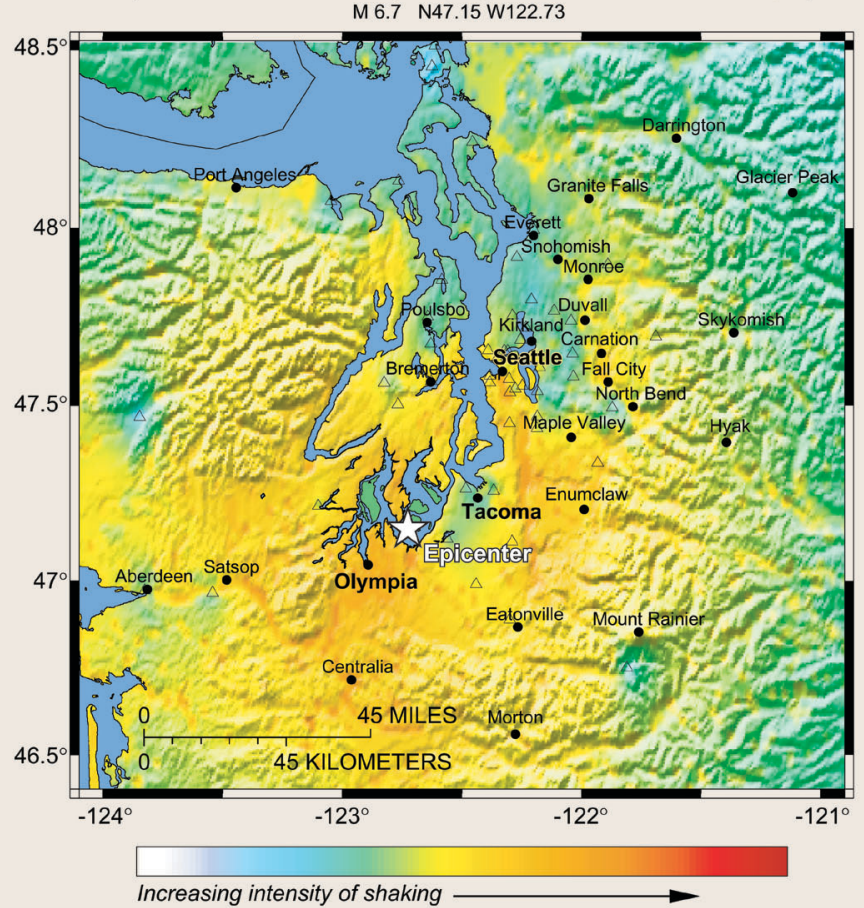

This U.S. Geological Survey (USGS) "ShakeMap" shows shaking intensities during the 2001 magnitude 6.7 Nisqually, Washington, earthquake, which caused \$2 billion in damage and economic losses in the Olympia-Seattle area. The capability to automatically generate computer maps of the intensity of ground shaking and to provide them to the public on the Internet within minutes of a quake was developed after the 1994 Northridge, California, earthquake. ShakeMaps help greatly in the quick assessment of the scope of an earthquake emergency and in guiding emergency response. ShakeMap requires data from modern seismic networks with digital strong-motion recording capabilities and real-time telecommunications feeds. Currently, few urban areas in the United States possess such networks. For this reason, ShakeMap is currently available only in the Los Angeles, San Francisco, Seattle, and Salt Lake City areas. Full implementation by the USGS of the Advanced National Seismic System (ANSS) will allow expansion of ShakeMap to all large U.S. metropolitan areas with moderate to high seismic risk.

The USGS Earthquake Hazards Program has also realized major improvements in its ability to provide timely and informative earthquake reports and information. To fulfill its Federal responsibility to monitor seismic activity in the United States, USGS operates the U.S. National

\section{DISCOVERING HIDDEN FAULTS}

Discovering active faults in thickly vegetated regions, such as the Puget Sound area of Washington (photo), is very challenging because their topographic expressions are hard to see. However, a new airborne laser technology, called LIDAR (light detection and ranging), is fast changing this. LIDAR imaging can see through forests to permit highresolution measurement of topography to a precision of a foot or less, showing otherwise invisible faults. Using LIDAR, the U.S. Geological Survey has been able to identify previously unknown faults in the Seattle and Puget Sound area. The LIDAR image at right reveals the Toe Jam Hill Fault, marked by a conspicuous east-west topographic trend (arrows). In addition, the image shows north-south grooves in the

Earth's surface that were formed by the movement of ancient glaciers.

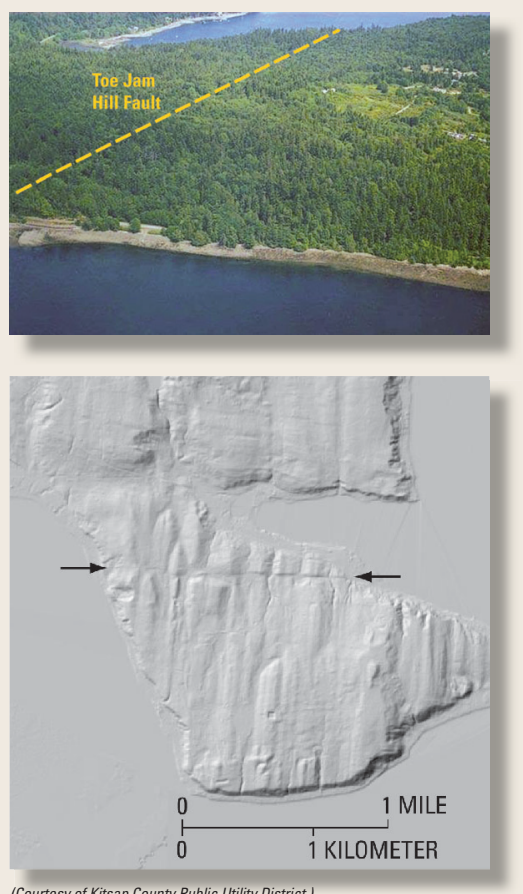

(Courtesy of Kitsap County Public Utility District.)

Seismograph Network, the National Earthquake Information Center, and the National Strong Motion Program and supports 14 regional seismic networks in areas of moderate to high quake activity. Additionally, the USGS, in cooperation with the National Science Foundation (NSF), operates the Global Seismic Network, which provides the main source of worldwide earthquake information.

USGS has capitalized on the revolution in information technology to achieve dramatic advances in real-time seismic-data analysis and rapid earthquake notification. The most noteworthy result of this is "ShakeMap," a system for automatically generating, within minutes of an earthquake, maps of areas subjected to strong shaking. ShakeMap, where available, can be delivered in 10 minutes or less and thus forms the basis for emergency response by cities, states, Federal agencies, and lifeline operators.

Complementing ShakeMap are a suite of other real-time earthquake products, such as earthquake paging and e-mail services, real-time earthquake location maps, automatic Web pages with information on significant events, and aftershock probability estimators. Additionally, USGS

\section{INSTRUMENTED BUILDINGS PROVIDE CRUCIAL DATA}

To design safer buildings and to provide vital information for strengthening older ones, U.S. Geological Survey earthquake engineers have installed arrays of seismic instruments in several buildings, such as San Francisco's Transamerica tower (right), in order to capture their motion during earthquakes. The resulting records reveal how structural systems perform in quakes and how shaking is amplified on upper floors, as demonstrated here by records from the tower during the 1989 Loma Prieta earthquake. In that quake, 63 people were killed when other structures collapsed. A major objective of the Advanced National Seismic System (ANSS) is to instrument many representative building types and key structures across the country to acquire the data that engineers need to help prevent loss of life in future quakes.

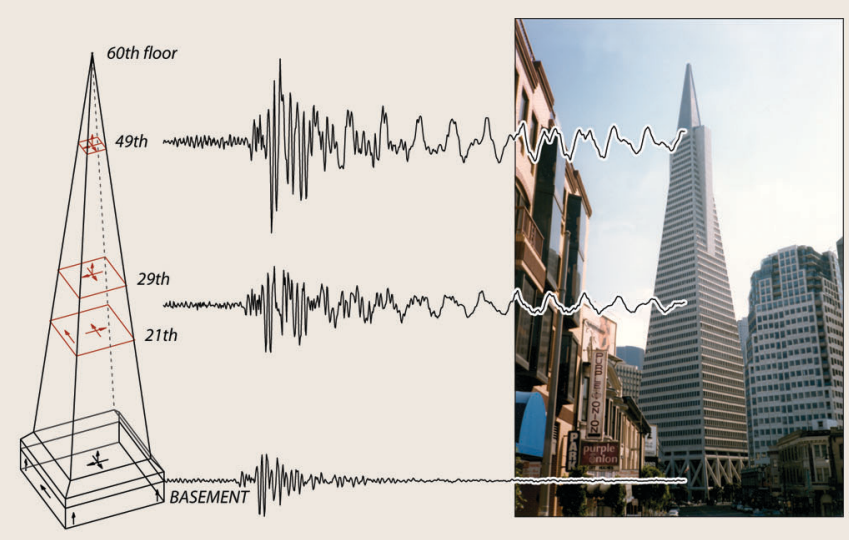




\section{HELPING THE PUBLIC PREPARE FOR EARTHQUAKES}
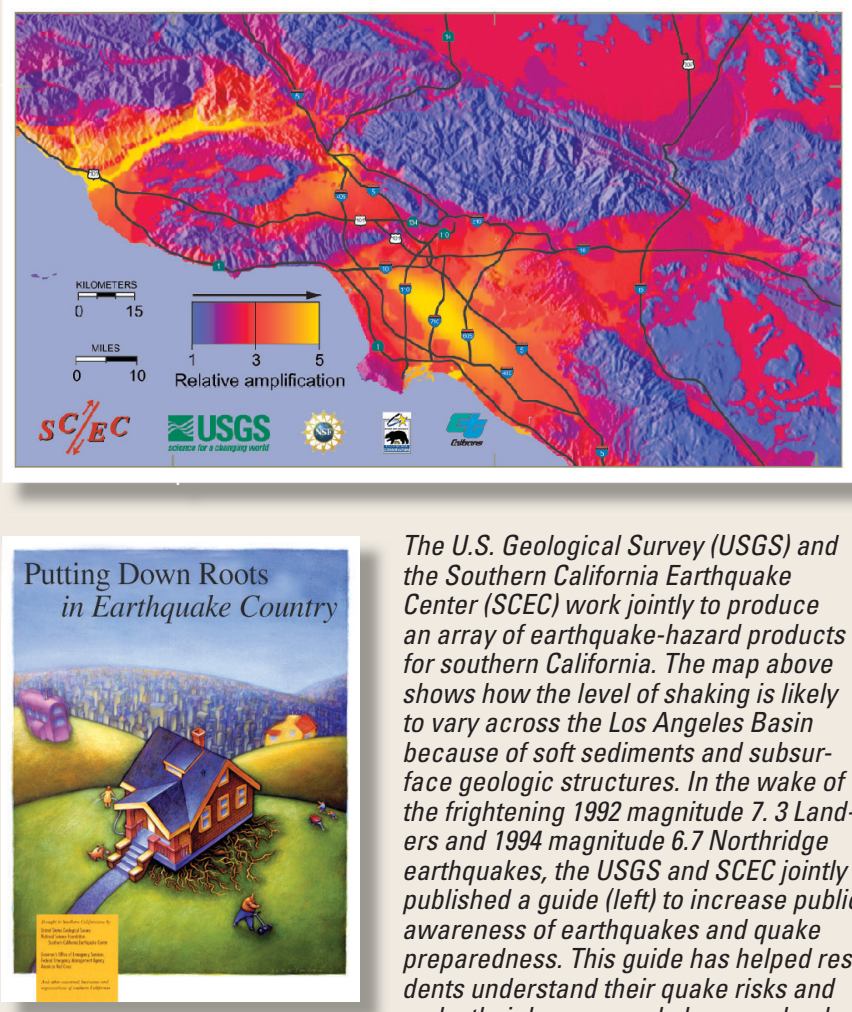

The U.S. Geological Survey (USGS) and the Southern California Earthquake Center (SCEC) work jointly to produce an array of earthquake-hazard products for southern California. The map above shows how the level of shaking is likely to vary across the Los Angeles Basin because of soft sediments and subsurface geologic structures. In the wake of the frightening 1992 magnitude 7. 3 Landers and 1994 magnitude 6.7 Northridge earthquakes, the USGS and SCEC jointly published a guide (left) to increase public awareness of earthquakes and quake preparedness. This guide has helped residents understand their quake risks and make their homes, workplaces, schools, and families safer in earthquakes. More than 1.8 million copies of the guide were distributed in southern California through schools, libraries, community centers, and local government offices. More than 3.5 million copies of a similar guide were distributed in the San Francisco Bay region after the 1989 magnitude 6.9 Loma Prieta earthquake. To commemorate the 10th anniversary of the Northridge earthquake, updated English and Spanish guides will be published in 2004.

has created a Web-based interface, called "Did You Feel It?," to provide Internet users with a means of reporting individual quake experiences that are compiled into maps of ground-shaking intensity. This suite of products provide the general public with rapid and comprehensive information about U.S. and global earthquakes when they need it most.

During the past 10 years, the demand for USGS earthquake-information products, including national and regional hazard maps and data from realtime seismic monitoring, has skyrocketed. USGS information now directly underpins local, state, and national earthquake loss-reduction and emergency response efforts.

\section{The Future of the USGS Earthquake Hazards Program}

The USGS Earthquake Hazards Program is poised to build on its accomplishments. The USGS will continue to improve on existing earthquake monitoring, assessment, and research activities, with the ultimate goal of providing the Nation with a new generation of earthquake products that more effectively promote earthquake mitigation and better facilitate earthquake response. At the heart of this effort will be a continued emphasis on delivering information that is useful, accessible, and easily understood. By working closely with policymakers and emergency planners, USGS will ensure that they have the most reliable and accurate information possible about earthquake hazards and that USGS products are tailored to their needs. USGS will participate in local and national earthquake-mitigation planning exercises and help train emergency responders, contingency planners, risk managers, the media, and others in how to use earthquake-hazard assessments and real-time information products. USGS will also continue to interact directly with communities to help them understand their vulnerabilities to earthquakes and to plan mitigation actions. Critical decisions for earthquake preparedness and response, including those that ensure uninterrupted corporate and government operations, are often made far from areas of high seismic hazard. So that informed and appropriate actions can be taken, USGS will continue to work to ensure that earthquake-hazard information and products are useful and familiar to decisionmakers, even in regions of low seismic hazard.

The USGS is committed to providing the Nation with new and useful products to reduce earthquake losses and improve quake safety. However, many needs cannot be met or opportunities seized under current funding levels. Critical among those needs and opportunities are:

Completing the Advanced National Seismic System - A major obstacle to further reducing loss of life and property in earthquakes is the present scarcity of strong-motion recordings of actual ground-shaking levels in urban areas and of the dynamic performance of structures and lifelines in quakes. The Advanced National Seismic System (ANSS) is intended to address this need by providing a nationwide network of least 7,000 sophisticated shaking monitors placed both on the ground and in buildings, mostly in seismically active urban areas. The closely spaced ANSS stations will be used to identify areas with specific problems, such as high amplification and focusing of seismic waves, and provide data crucial for finding cost-effective seismic-design solutions.

One critical component of ANSS is the instrumentation of buildings, bridges, and other structures. It is essential to have multiple structures in highhazard areas instrumented with arrays of seismometers so that engineers can understand how different types of buildings respond to earthquake shaking. These instruments will also provide crucial information on:

- The coupling between building foundations and underlying soils,

- The role of torsion of columns in building shaking,

- The performance of commonly used structural systems, such as shear walls combined with a moment-frame structure, and

- The ability of mathematical models to predict the performance of structures during strong shaking.

Another urgent need that will be addressed by ANSS is improved reliability, timeliness, and usefulness of USGS real-time earthquake products for

In November 2002, the powerful magnitude 7.9 Denali Fault earthquake struck south-central Alaska, rupturing the ground beneath the zigzagging TransAlaska Oil Pipeline. Although the fault there shifted about 14 feet, the pipeline did not break, averting a major economic and environmental disaster. This success was largely the result of a design based on geologic and engineering studies done by the U.S. Geological Survey and others. Alaska has the greatest exposure to earthquake hazard of any state. The impact of a devastating quake in Alaska could extend far beyond its borders, both by generating deadly tsunamis and through economic consequences.






\section{SEISMIC-HAZARD INFORMATION HELPS ENSURE THE SURVIVAL OF STRUCTURES AND LIFELINES}

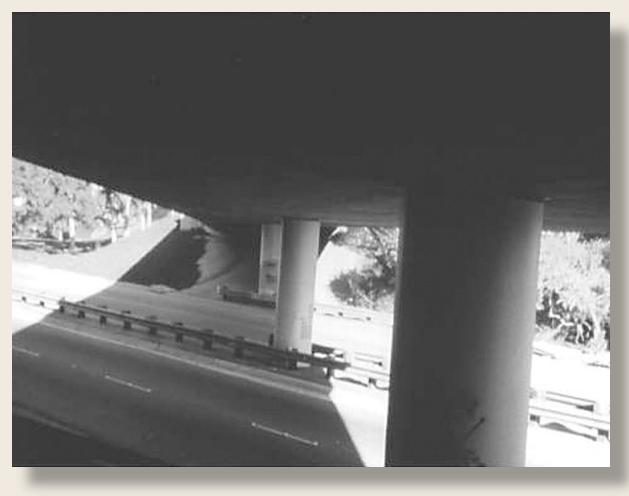

RETROFITTED HIGHWAY OVERPASS

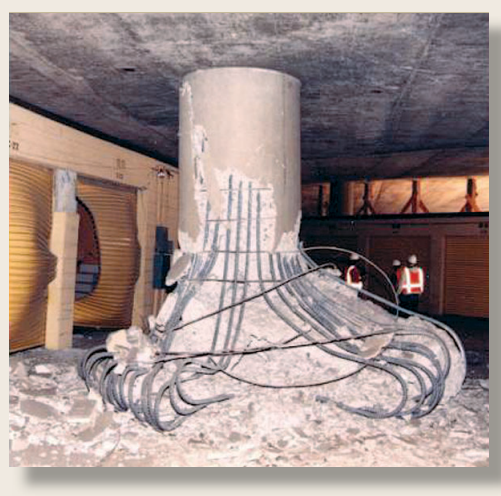

NON-RETROFITTED OVERPASS
U.S. Geological Survey (USGS) seismic-hazard information is used by structural engineers to design structures and lifelines, such as freeway overpasses, to help ensure their survival in quakes. Over the past 25 years, USGS and other scientists have discovered that quakes can shake the ground much more violently than provided for in earlier building codes. The California Department of Transportation (Caltrans) has nearly completed a program of retrofitting bridges and overpasses throughout the State. In 1994, when the magnitude 6.7 Northridge earthquake struck Los Angeles, the success of this investment was demonstrated. Retrofitted bridge columns in areas of severe to violent shaking (such as those at left) survived with minor or no damage, whereas non-retrofitted overpass supports (such as the one at right) collapsed. Caltrans is now beginning to use USGS "ShakeMaps" to expedite their post-earthquake response, enabling emergency managers to focus field inspections on the most severely shaken areas. (Photos courtesy of Caltrans.) emergency-response purposes. ShakeMap, in particular, requires access to a modern seismic network with digital strong-motion recording capabilities and real-time telecommunications feeds. Currently, few urban areas in the United States possess such a network. Full implementation of ANSS will allow expansion of ShakeMap to all large U.S. metropolitan areas with moderate to high seismic risk.

\section{Acquiring essential data for expanded urban hazard assess-} ments-Most current USGS earthquake-hazard assessments are compiled on regional or national scales. These estimates typically assume uniform firm soil conditions, as opposed to the varying actual soil conditions beneath cities and lifelines. At the scales required for urban planning and development, assessments need to account for the amplifying effects of soils, as well as the potential for ground failures, such as liquefaction and landslides.

USGS pilot urban assessments in Oakland, Seattle, and Memphis have shown the usefulness of detailed urban seismic assessments. USGS must expand this effort to include other urban centers at risk from earthquakes. Central to this endeavor will be the acquisition of data on local geology, site conditions, and ground motions needed to produce detailed urban seismichazard maps. These data-acquisition efforts will require additional resources that will in part be used to help support expanded partnerships with state geological surveys and local government agencies. As these urban hazard assessments evolve, they will allow estimates to be made for potential earthquake losses to buildings and critical lifelines. This is one of the keys to developing cost-effective mitigation strategies to reduce future earthquake losses.

Expanding activities in the Eastern United States-The USGS Earthquake Hazards Program devotes approximately $75 \%$ of its resources to work in the Western United States, primarily because earthquakes occur more frequently there. However, history demonstrates that a catastrophic quake could also strike a major city in the Eastern United States. Four damaging earthquakes with magnitudes greater than 7 centered in the New Madrid, Missouri, area struck the Mississippi Valley in 1811-12. Charleston, South Carolina, was devastated by a magnitude 6.7 shock in 1886, and a magnitude 6 quake struck the Boston area in 1755.

USGS studies show that urban areas in the Eastern United States face far greater damage and far more deaths in a quake of a given magnitude than those in the West for several reasons: (1) For the same magnitude earthquake, severe shaking affects a much larger area, (2) most structures are not designed to resist earthquakes, and (3) population density is high and residents are not routinely educated about seismic safety.
USGS has been developing the understanding and methods that can form the groundwork for a substantial effort in the East, where earthquake faults are rarely exposed at the surface and the subsurface conditions beneath major cities are poorly documented. More thorough and accurate assessment of the seismic risk faced by major urban centers in the East will reveal the greatest vulnerabilities and provide information that is essential to evaluating possible mitigation strategies.

Expanding activities in Alaska-Alaska has the greatest exposure to earthquake hazard of any state. Because of the relatively small urban population, many people assume that the risk is low in comparison to the rest of the country. However, the impact of a devastating quake in Alaska can extend far beyond its borders, both by generating deadly tsunamis (seismic sea waves) and through economic consequences. Alaska is a major source of natural resources for the rest of the Nation, a major transportation and commercial node of the Pacific Rim, and of significant importance to national defense.

Capitalizing on new national facilities - As described in the 2003 National Research Council report, Living on an Active Earth: Perspectives

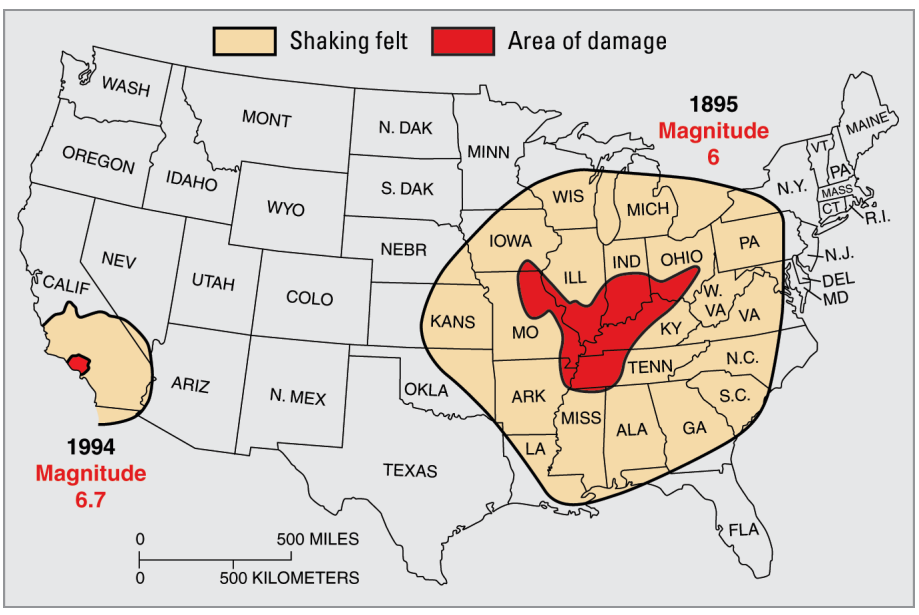

In the Central and Eastern United States, earthquakes are felt over a broader area than comparable-size quakes in the Western United States because of differences in geology. Although only of magnitude 6, the earthquake that occurred near Saint Louis in 1895 affected a larger area than the 1994 magnitude 6.7 Northridge, California, quake, which caused $\$ 40$ billion in damage and economic losses and killed 67 people. A repeat of the 1895 earthquake could prove disastrous for the Midwest, where structures are not as earthquake resistant as those in California. 


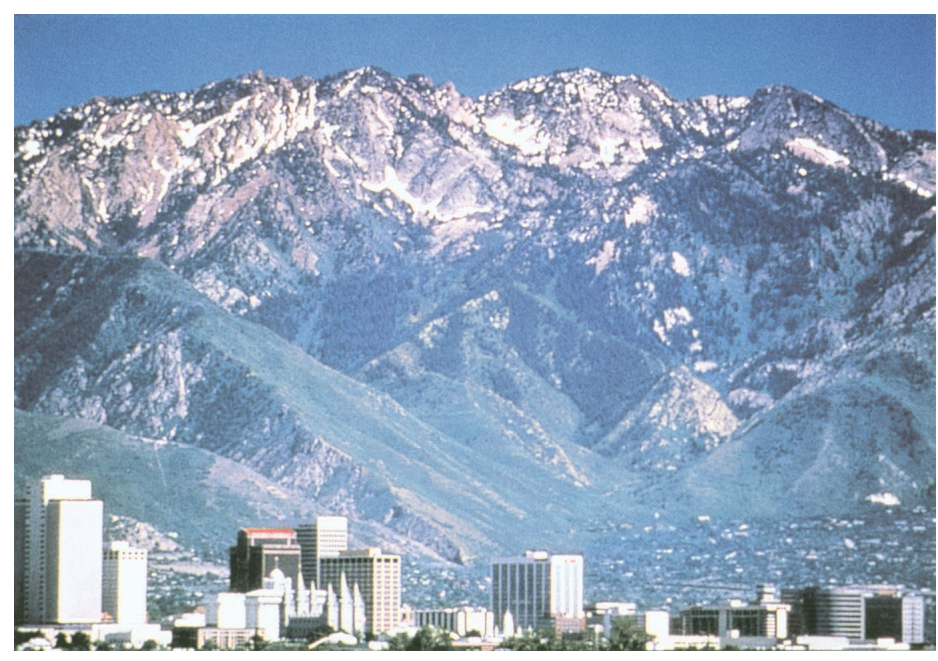

Earthquakes pose a significant threat to urban areas in the Intermountain West. For example, almost 75\% of Utah's population lives near the Wasatch Fault. Movement on this fault in past quakes has uplifted the Wasatch Range to form a spectacular backdrop for the state's three largest cities, including Salt Lake City, shown here. U.S. Geological Survey and Utah State Geological Survey scientists have shown that this fault has repeatedly generated earthquakes of magnitude 7 or larger and will continue to do so in the future. Efforts to increase public awareness of earthquake hazards in Utah have resulted in residents and community leaders taking actions that will save lives and reduce damage in future quakes. (Photo courtesy of the Salt Lake Convention and Visitors Bureau.)

on Earthquake Science, continued progress toward evaluating earthquake hazards will increasingly require integrative, physics-based research involving theoretical studies of processes controlling earthquake phenomena, sophisticated numerical modeling, ground- and space-based field observations, and laboratory simulations. Recent and proposed U.S. Government investments in major earth-science and engineering facilities include ANSS, the NSF-coordinated EarthScope program (including the Plate Boundary Observatory, USArray, and the San Andreas Fault Observatory at Depth), the NSF Network for Earthquake Engineering Simulation (NEES), and a future interferometric synthetic aperture radar (InSAR) satellite mission. These facilities will be able to offer, for the first time, the breadth and depth of data required to truly understand the physical nature of earthquakes.

The USGS will take advantage of these new data streams to conduct earthquake-hazard-focused experiments on scales never before possible. To improve long-term hazard assessments, USGS will also use these data together with advanced computational methods to simulate the multiple factors controlling earthquakes within specific fault systems. A major goal will be to understand the criteria for the occurrence of quakes within a fault system and the impact of one quake on the system through the many processes that transfer stresses. To determine the feasibility of short-term prediction of earthquakes, USGS will build new mathematical models of quake likelihood, akin to weather-forecast models.

\section{Conclusion}

After 25 years of NEHRP, the USGS Earthquake Hazards Program is the world scientific leader in seismic-hazard studies. In implementing the results of these studies to mitigate the effects of earthquakes, USGS has actively collaborated with state geological surveys, emergency-response officials, earthquake engineers, local governments, and the public. This collaboration has resulted in dramatic improvements in earthquake preparedness and public safety in the United States, but there is still much work to be done. By integrating USGS earthquake information with data from new national initiatives, such as ANSS, USGS will be able to meet the need for a new generation of
CREATING TIME-DEPENDENT EARTHOUAKE PROBABILITY MAPS

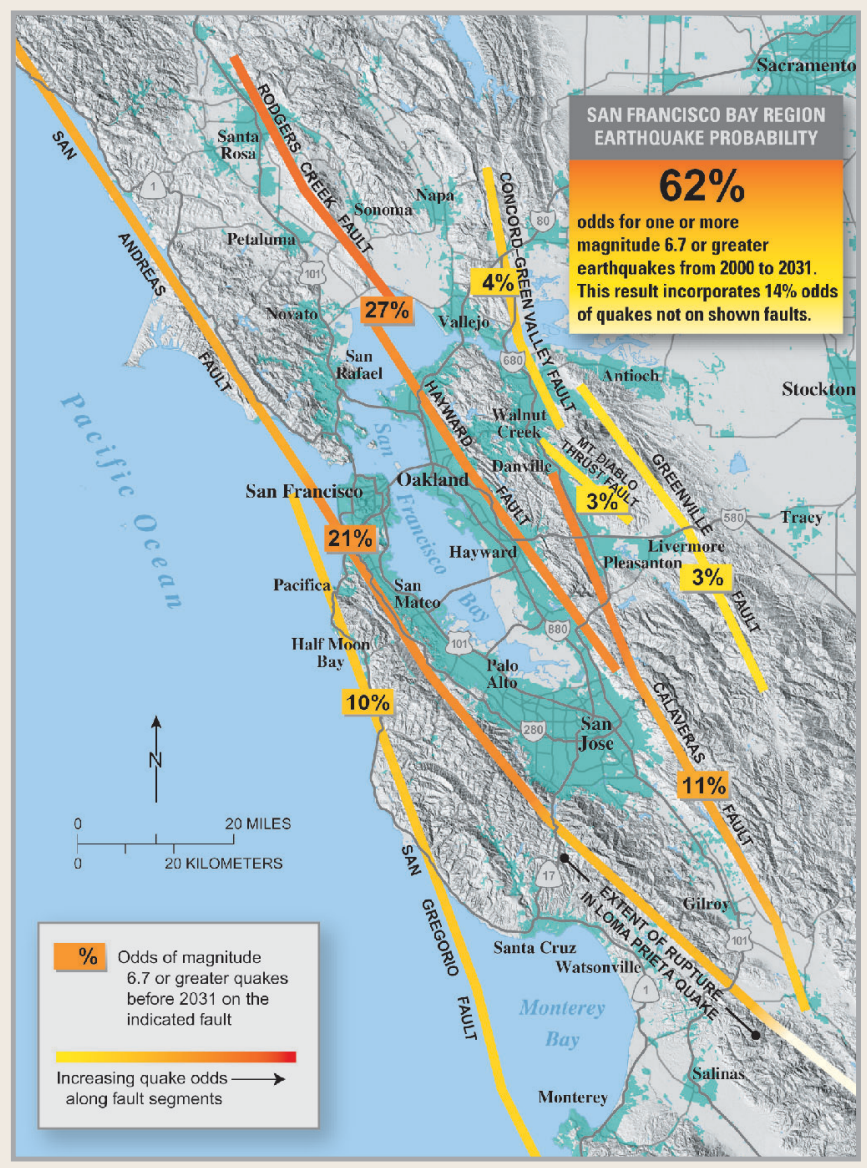

Time-dependent earthquake probability maps take into account the effects of quake occurrence and fault interactions on the likelihood of future quakes. In 1988, the first U.S. Geological Survey (USGS) map of this type correctly identified the future site of the 1989 magnitude 6.9 Loma Prieta earthquake. On the basis of research conducted since that quake, USGS and other scientists conclude that there is a $62 \%$ probability of at least one magnitude 6.7 or greater quake, capable of causing widespread damage, striking the San Francisco Bay region before 2031. This periodically updated information is widely disseminated to the public in both the print and broadcast media, as well as in USGS publications, and is being used to focus preparedness efforts throughout the bay region.

earthquake hazard-assessment and mitigation tools. These tools will be used to further reduce losses of life and property in the future earthquakes that are certain to strike the Nation.

John R. Filson, Jill McCarthy, William L. Ellsworth, and Mary Lou Zoback Edited by

Peter H. Stauffer and James W. Hendley II

Graphic design by

Sara Boore, Susan Mayfield, and Stephen L. Scott, and Eleanor Omdahl

For further information contact:

U.S. Geological Survey, Mail Stop 905

12201 Sunrise Valley Drive

Reston, VA 20192

(703) 648-6714

http://earthquake.usgs.gov/

This Fact Sheet and any updates to it are available online at http://geopubs.wr.usgs.gov/fact-sheet/fs017-03/ 